\title{
Physiological and Growth Responses to Irrigation of a Newly Established Hedgerow Olive Orchard
}

\author{
Maria Gomez-del-Campo \\ Depto de Producción Vegetal: Fitotecnia, Universidad Politécnica de \\ Madrid, Ciudad Universitaria sn. 28040 Madrid, Spain
}

Additional index words. leaf conductance, stem water potential, trunk diameter, shoot growth, superintensive olive orchard

\begin{abstract}
Olive production in the first few years after planting depends on how the canopy covers the hedgerow and develops flowers. Therefore, optimum irrigation management should look for the minimum amount of water required for maximum growth and bud initiation. The response of a young hedgerow olive orchard to different irrigation strategies was recorded for 3 years after planting in 2003. Observations included stem water potential ( $\left.\Psi_{\text {stem }}\right)$, leaf conductance $\left(g_{1}\right)$, shoot and trunk growth, canopy development, and flowering. During the first year, olives received $74 \mathrm{~mm}$ of irrigation. During the second and third years, three irrigation treatments $(\mathrm{T} 2, \mathrm{~T} 3$, and $\mathrm{T4})$ were scaled back from a control (T1) that was irrigated to maintain soil close to water-holding capacity. T1 received 56 and $106 \mathrm{~mm}$ of irrigation in the second and third years, respectively. Treatments T2, T3, and T4 received $82 \%, 64 \%$, and $46 \%$ of the water applied to $\mathrm{T} 1$ in the second year and $76 \%, 72 \%$, and $29 \%$ in the third year of growth, respectively. Trees in T1 displayed different physiological and growth behaviors between years. $\Psi_{\text {stem }}, g_{\mathrm{l}}$, and shoot growth were $131 \%$, $31 \%$, and $56 \%$ lower in the third than in the second year, respectively. Irrigation treatment had no significant effect on evaluated parameters in the second year, except on $\Psi_{\text {stem }}$ in $T 4$ that fell below that of the other treatments in late September. In the third year, shoot growth, trunk diameter, and leaf area density in T4 decreased $52 \%, 13 \%$, and $31 \%$ compared with $\mathrm{T} 1$, respectively. Nevertheless, external surface area and canopy volume were not significantly affected by irrigation treatment. The start of flowering, recorded in the third and fourth years, was not significantly affected by the irrigation received in previous years. Because water stress did not advance flowering, maximum growth should be the main objective in irrigation management of young olive orchards. No differences were observed between $\mathrm{T} 3$ and $\mathrm{T} 1$ in any of the vegetative, canopy development, or inflorescence parameters recorded, although $\Psi_{\text {stem }}$ and $g_{I}$ were significantly lower in $T 3$. During the second and third years, $T 3$ can be considered the most efficient irrigation treatment with 36 and $76 \mathrm{~mm}$ of irrigation for each year, respectively.
\end{abstract}

The first results of studies with hedgerow or superhigh-density orchards (714 to 1975 olive/ha) were reported in Italy by Morettini (1972). However, it was not until the 1990s that this production system was commercially adopted. Since then, it has spread rapidly worldwide, currently accounting for an area of $\approx 40,000$ ha with a growth rate of 10,000 ha

Received for publication 17 Nov. 2009. Accepted for publication 26 Feb. 2010.

This research was supported by the Universidad Politécnica de Madrid (Project A0409) and the Universidad Politécnica de Madrid and the Comunidad de Madrid (Project R05/11243).

I express my gratitude to David J. Connor and anonymous reviewers for suggestions on the manuscript; José Ramón Lissarrague for the use of research equipment; Vicente Gómez for the soil description; and Beatriz Suarez, Pilar Tejela, Francois Camsusou, Antonio Leal, Carlos Pezuela, Ana Centeno, and Jaime Quiroga for helping in field data collection. I gratefully acknowledge the Instituto Madrileño de Investigación y Desarrollo Rural Agrario y Alimentario (IMIDRA) of the Comunidad de Madrid for access to the olive orchard where this research was conducted. e-mail maria.gomezdelcampo@upm.es. per year. The objective of this system is to obtain high yields from the early years of establishment and an orchard structure suited to mechanical pruning and harvesting. In these orchards, trees are usually pruned to a central leader and fruits are harvested with modified grape harvesters.

Early high yield is achieved by reducing the unproductive period that is determined by cultivar, edaphoclimatic conditions, and orchard management practices. However, shoots need time both to occupy the entire hedgerow and to adequately develop reproductive (flower) buds. These two aspects are inversely related because vegetative vigor is inimical to reproductive development. Irrigation management impacts these components of the unproductive period in different ways. Water stress is well known to reduce vegetative growth and to stimulate flowering in various woody plants (Meilan, 1997). Although water stress closes stomates, reducing photosynthesis and growth, its effect on flowering is less certain. It may be the result of a direct effect of hormone production on flower initiation or increased nutrient concentration in growing buds. Abscisic acid (ABA), an antigiberelic acid, has been reported (Davies et al., 1986) as the most important water stress hormone in plants. In olive, Kitsaki and Drossopoulos (2005) reported increased ABA in leaves of stressed plants, which was negatively related to leaf water potential, whereas Baktir et al. (2004) found that high $\mathrm{ABA}$ concentrations and low gibberellic acid favor olive bud initiation. This could explain the increase in the number of inflorescences per shoot observed in water stressed olives by Gucci et al. (2007).

$\mathrm{Cv}$. Arbequina is mainly used in hedgerow olive orchards because of its short unproductive period, but it is less resistant to frost than 'Cornicabra', the most important cultivar in the Center Region of Spain (269,000 ha) (Barranco, 2008). In this study, the effect of different irrigation treatments on a young olive orchard during the unproductive period was evaluated in the Center Region of Spain, characterized by low fall and winter temperatures. A 2-year-old hedgerow orchard of 'Cornicabra' was subjected to four irrigation regimes during the second and third years after planting to determine if water stress could be useful for enhancing early olive fruit production. Stem water potential and leaf conductance were measured and their effect on vegetative growth, canopy development, and flowering was evaluated. Additional data of the third growth period have been published previously (Gómez-del-Campo et al., 2008). The relationships among stem water potential, vegetative growth, and soil water status were also studied.

\section{Materials and Methods}

The site. The experiment was conducted at the Olive Production Center of the Comunidad de Madrid, Colmenar de Oreja, Spain (lat. $40^{\circ} 04^{\prime} \mathrm{N}$; long. $03^{\circ} 31^{\prime} \mathrm{W}$; altitude $524 \mathrm{~m}$ ). Soil is clay loam (Xerochrept calcixerollic) with an effective rooting depth of $1 \mathrm{~m}$. Soil description shows that two horizons were developed: $0.45 \mathrm{~m}$ depth of Horizon A followed by $0.55 \mathrm{~m}$ of Horizon B. Rocks represented $1 \%$ and $9 \%$ of soil volume in each horizon, respectively. Water content at field capacity was $23.3 \%$ and $29.3 \%(\mathrm{v} / \mathrm{v})$ for Horizons $\mathrm{A}$ and $\mathrm{B}$, respectively, whereas wilting point was $13.1 \%$ and $12.4 \%(\mathrm{v} / \mathrm{v})$ for each horizon, respectively. Considering a coefficient of allowable depletion of 0.5 , readily available water to $1-\mathrm{m}$ depth was $65 \mathrm{~mm}$. A weather station at the site registered wind speed and direction, rainfall, temperature, humidity, and global radiation every $30 \mathrm{~min}$ and calculated vapor pressure deficit (VPD) and evapotranspiration (ETo) by the PenmanMonteith method (Allen et al., 1998) from these climatic variables. Mean annual temperature from data recorded over 30 years was $14{ }^{\circ} \mathrm{C}$ with a mean minimum temperature of $-11^{\circ} \mathrm{C}$ in January.

Irrigation treatments. On 9 June 2003, an area of $2500 \mathrm{~m}^{2}$ was planted with cv. Cornicabra at a spacing of $3.75 \times 1.8 \mathrm{~m}$ (1481 olive/ ha). Trees were trained to a central leader during the first 3 years. Irrigation was by drip emitters of $2 \mathrm{~L} \cdot \mathrm{h}^{-1}$ at $0.60-\mathrm{m}$ spacing in a single 
line for each row of trees. Weeds were controlled using a nonresidual herbicide, and fertilizer was applied according to leaf analyses carried out each year in July. After planting, trees received $149 \mathrm{~mm}$ of irrigation to compensate for low soil water content. Subsequently, trees were irrigated according to the continuous readings of six Watermark ${ }^{\mathrm{TM}}$ sensors connected to a data logger (Irrometer, CA) located in pairs at $0.3-\mathrm{m}$ depth and $0.3 \mathrm{~m}$ from the emitters and trunk (emitter was near the trunk) of three representative trees. Irrigations of $8 \mathrm{~h}$ were applied when the mean value of the sensors indicated a soil water potential of $-0.015 \mathrm{MPa}$ from spring until 15 Aug. and $-0.03 \mathrm{MPa}$ from $15 \mathrm{Aug}$. until the end of September (mean $\mathrm{CV}=23 \%$ ). Two detailed measurements at the experimental site revealed that this irrigation duration corresponds to the arrival of the wetting volume at 0.9-m depth and therefore to the potential effective rooting depth without excessive drainage. From 19 June 2003 to 13 Sept. 2003, the orchard received a total of $74 \mathrm{~mm}$ irrigation.

At the beginning of the second season, on 24 June 2004, a general irrigation of $6 \mathrm{~mm}$ was applied to all trees to wet the soil. On 5 July, four irrigation treatments (T1 to T4) were established in a completely randomized fourblock design. Each replicate consisted of 21 trees (five control and 16 border). T1 trees were irrigated for $8 \mathrm{~h}$ when the mean value of all the Watermark ${ }^{\mathrm{TM}}$ sensors indicated a soil water potential of $-0.03 \mathrm{MPa}$ from spring until 15 Aug. and $-0.06 \mathrm{MPa}$ from 15 Aug. until 30 Sept. On those days, T2, T3, and T4 trees were irrigated with $80 \%, 60 \%$, and $40 \%$ of the water applied to $\mathrm{T} 1$, respectively. Thus, over the entire irrigation period (24 June to 15 Sept.), treatments T1, T2, T3, and T4 received $56,46,36$, and $26 \mathrm{~mm}$, respectively.

At the beginning of the third season on 20 May 2005, a general irrigation of $6.2 \mathrm{~mm}$ was applied to all treatments. T1 was then watered like in the second season, whereas $\mathrm{T} 2, \mathrm{~T} 3$, and $\mathrm{T} 4$ were again irrigated on the same days as T1 but with $75 \%, 50 \%$, and $25 \%$ of the water applied to T1, respectively. The treatments were maintained until 4 Sept., and then on 29 Sept., all treatments received $7 \mathrm{~mm}$ of irrigation. It should be noted that on 13 June, T3 received $31 \mathrm{~h}$ of irrigation as a result of valve failure. To compensate, no water was applied at the next scheduled irrigation. Thus, over the entire irrigation period, trees in $\mathrm{T} 1, \mathrm{~T} 2, \mathrm{~T} 3$, and $\mathrm{T} 4$ received 106, 81, 76, and $31 \mathrm{~mm}$ of irrigation, respectively.

Soil and plant water status and leaf conductance. Soil water potential $\left(\Psi_{\text {soil }}\right.$, $\mathrm{MPa})$ was measured weekly from 21 June 2004 to 28 Sept. 2004. Two gypsum blocks (Delmhorst, Towaco, NJ) were placed at $0.50-\mathrm{m}$ depth and $0.30 \mathrm{~m}$ from trunks per replicate and treatment. In 2005 , soil water content $(\theta, \%)$ was measured weekly at 0.10 $\mathrm{m}$ intervals to $1 \mathrm{~m}$ at least $3 \mathrm{~d}$ after irrigation from 9 June to 7 Oct. using a portable capacitance probe (Diviner 2000; Sentek Pty. Ltd., Stepney, Australia). One access tube of $1.5-\mathrm{m}$ length was installed in each block and treatment at a distance of $0.30 \mathrm{~m}$ from a drip emitter and an olive trunk. The effect of irrigation treatment on stem water potential $\left(\Psi_{\text {stem }}, \mathrm{MPa}\right)$ and leaf conductance $\left(\mathrm{g}_{1}, \mathrm{mmol}\right.$ $\mathrm{H}_{2} \mathrm{O} / \mathrm{m}^{2} / \mathrm{s}$ ) was measured in one shoot tip or leaf of four trees per treatment in one block. Every week during the experimental period (from July to Sept. 2004 and from June to Oct. 2005), $\Psi_{\text {stem }}$ was measured at solar noon (11:45 to $12: 15 \mathrm{HR})$ in four shoots near the trunk on the shaded side of the row using a pressure chamber (Soil Moisture Equip., Santa Barbara, CA). The shoots had previously been covered with aluminium foil for $1 \mathrm{~h}$ (McCutchan and Shackel, 1992) to allow the leaf to come into equilibrium with the water potential of the stem (Begg and Turner, 1970). Leaf conductance was measured at solar noon on four healthy leaves exposed to the sun using a steady-state porometer (Li-1600; LI-COR, Lincoln, NE). Soil moisture, vegetative growth, $\Psi_{\text {stem }}$, and $\mathrm{g}_{1}$ measurements were taken on the same days.

Vegetative growth and canopy characteristics. Plant height and stem diameter at $0.30-\mathrm{m}$ height were measured on the day of planting (9 June 2003) in 10 randomly selected nursery trees. All leaves were then removed and leaf area per tree was measured with an area meter (Li-3100; LI-COR). In 2004 and 2005, trunk diameter at the base and the length of one shoot were measured weekly on three trees of each replicate. At the end of each season, leaf area per tree was estimated by measuring the diameter of all branches on the experimental trees and applying the regression: leaf area $\left(\mathrm{m}^{2}\right)=0.0002 \mathrm{x}^{2.75}\left(R^{2}=\right.$ $\left.0.69^{* *}\right)$, where $\mathrm{x}=$ branch diameter $(\mathrm{mm})$, measured at the base just below the first leaf of 15 sampled branches. The leaves on these branches were removed and leaf area was measured with an area meter. Foliage architecture of the experimental trees was described at the end of 2005 (on 20 Sept.). The height of the top and bottom foliage was measured at nine positions per tree: above the trunk and at distances of $0.2,0.4,0.6$, and $0.8 \mathrm{~m}$ on both the east-west and north-south sides of the tree. Hedgerow external surface area and canopy volume were calculated by considering a monocone shape. This allowed the further calculation of leaf area density (leaf area/canopy volume) and number of horizontal leaf layers (leaf area/vertical canopy projection). Two digital photographs $(1 \times 1 \mathrm{~m})$ were taken in the center of each experimental tree canopy with a red sheet suspended behind it. Porosity was calculated using the digital analyzer program Erdas Imagine, Version 9.1 (Leica Geosystems Geospatial Imaging, Norcross, GA).

Flowering. The effect of irrigation on flowering was evaluated by counting the inflorescences on all of the experimental trees during the spring of two successive seasons on 16 June 2005 and 17 May 2006. Inflorescences were counted and removed from experimental trees to reduce growth variability resulting from the different number of fruits developed.

Data analysis. Data were subjected to analysis of variance using MSTAT-C (University of Michigan, Ann Arbor, MI). Least significant differences $(P<0.05)$ were used to separate treatment means using Duncan's multiple range test. Before analysis, percentage data were transformed by arcsine square root to a normal distribution.

\section{Results}

Environmental conditions. ETo, rainfall, and temperature from Oct. 2003 to Dec. 2005 are shown in Figure 1. The year 2004 was characterized by high rainfall $(646 \mathrm{~mm})$ and low ETo $(1318 \mathrm{~mm})$ compared with 2005 (206 mm of rainfall and $1409 \mathrm{~mm}$ of ETo). These values are consistent with mean rainfall and ETo values obtained during the last 25 years (347 and $1329 \mathrm{~mm}$, respectively). ETo was higher during the irrigation period in 2005 (24 June to 15 Sept.) ( $778 \mathrm{~mm}$ ) than in 2004 (20 May to 29 Sept.) (518 mm). Rainfall during the irrigation period was 117 and $30 \mathrm{~mm}$ in 2004 and 2005, respectively. Climatic conditions on the days of $\Psi_{\text {stem }}$ and $\mathrm{g}_{1}$ measurements in the 2004 and 2005 seasons are shown in Table 1 . The highest ETo value was recorded on 14 July 2005 $(10.7 \mathrm{~mm})$, whereas the lowest values were recorded on 10 Aug. 2004 (4.2 mm).

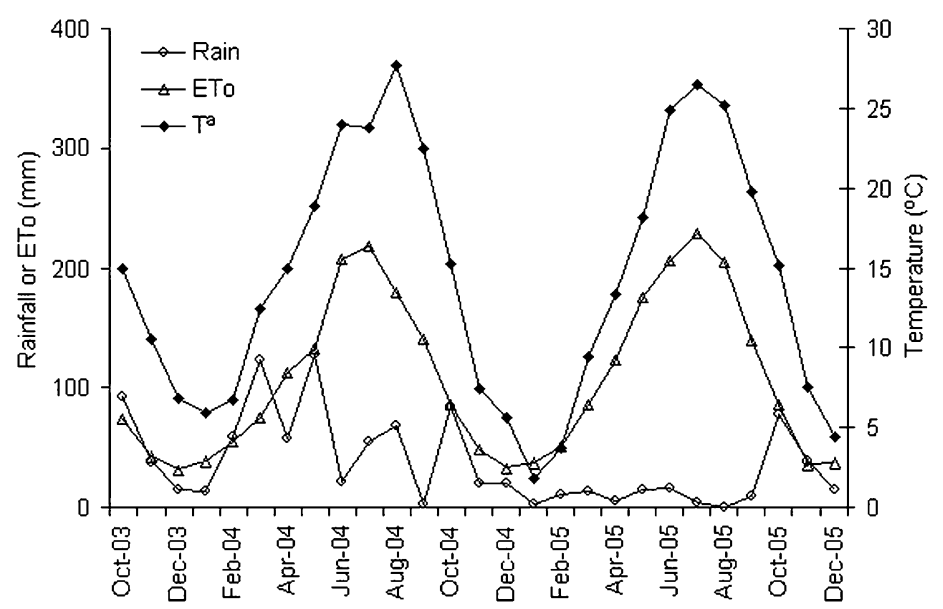

Fig. 1. Monthly rainfall, evapotranspiration, and mean temperature from Oct. 2003 to Dec. 2005 at the
Madrid Olive Production Center (Colmenar de Oreja, Spain).

1. Monthly rainfall, evapotranspiration, and mean temperature from Oct. 2003 to Dec. 2005 at the
Madrid Olive Production Center (Colmenar de Oreja, Spain).

HortScience Vol. 45(5) May 2010 
Soil water content. Soil water potential during the 2004 season is shown in Figure 2. Soil water potential in $\mathrm{T} 1$ was above -0.033 $\mathrm{MPa}$ until 15 Aug. when irrigation was reduced to harden trees for fall frost. The high $\Psi_{\text {soil }}$ in spring may have caused drainage, in which case part of the irrigation was not effective. T2 and T3 maintained $\Psi_{\text {soil }}$ values above - $0.033 \mathrm{MPa}$ until 10 Aug. 2004. These values were not significantly different from those of $\mathrm{T} 1$ as a result of high spring and summer rainfall $(114 \mathrm{~mm})$. However, T4 water content started to decrease on 27 July. After 3 Aug., $\Psi_{\text {soil }}$ in T4 fell significantly below that of T1. In 2004, mean $\Psi_{\text {soil }}$ of T2, $\mathrm{T} 3$, and T4 were $15 \%, 20 \%$, and $125 \%$ lower than that of $\mathrm{T} 1$, respectively.

The seasonal trend of soil water content $(\theta$, $\%$ ) in the wetted volume to a $1-\mathrm{m}$ depth in 2005 is also presented in Figure 2. Soil water content in T4 fell steadily from 26 May to 29 Sept., whereas $\mathrm{T} 1$ and $\mathrm{T} 2$ maintained high $\theta$ values until 7 July when they began to decrease. In $\mathrm{T} 1$ and $\mathrm{T} 2$, the highest $\theta$ during the

Table 1. Daily evapotranspiration (ETo), average temperature, and vapor pressure deficit (VPD) at solar noon on the days when leaf conductance and stem water potential were measured in 2004 and 2005

\begin{tabular}{rccccccc}
\hline & $\begin{array}{c}\text { ETo } \\
(\mathrm{mm} / \text { day })\end{array}$ & $\begin{array}{c}\text { Temp } \\
\left({ }^{\circ} \mathrm{C}\right)\end{array}$ & $\begin{array}{c}\text { VPD } \\
(\mathrm{kPa})\end{array}$ & & $\begin{array}{c}\text { ETo } \\
(\mathrm{mm} / \text { day })\end{array}$ & $\begin{array}{c}\text { Temp } \\
\left({ }^{\circ} \mathrm{C}\right)\end{array}$ & $\begin{array}{c}\text { VPD } \\
(\mathrm{kPa})\end{array}$ \\
\hline 6 July 2004 & 6.0 & 23.8 & 3.65 & 26 May 2005 & 7.7 & 25.7 & 3.57 \\
13 July 2004 & 6.7 & 22.3 & 3.64 & 9 June 2005 & 8.5 & 25.0 & 3.13 \\
20 July 2004 & 7.2 & 24.6 & 4.29 & 17 June 2005 & 9.5 & 28.6 & 3.59 \\
27 July 2004 & 7.7 & 26.0 & 4.31 & 30 June 2005 & 9.4 & 23.3 & 3.55 \\
3 Aug. 2004 & 4.8 & 24.6 & 2.81 & 14 July 2005 & 10.7 & 30.4 & 4.58 \\
10 Aug. 2004 & 4.2 & 19.3 & 1.64 & 28 July 2005 & 7.6 & 23.8 & 2.23 \\
18 Aug. 2004 & 5.2 & 22.2 & 2.71 & 4 Aug. 2005 & 8.1 & 25.3 & 3.55 \\
24 Aug. 2004 & 6.9 & 27.6 & 4.48 & 18 Aug. 2005 & 6.6 & 25.2 & 3.60 \\
31 Aug. 2004 & 5.8 & 23.5 & 4.02 & 25 Aug. 2005 & 8.7 & 29.4 & 5.00 \\
7 Sept. 2004 & 4.5 & 25.5 & 3.24 & 1 Sept. 2005 & 6.3 & 25.7 & 2.94 \\
14 Sept. 2004 & 4.2 & 19.4 & 2.63 & 8 Sept. 2005 & 4.9 & 19.0 & 1.74 \\
21 Sept. 2004 & 5.3 & 22.4 & 3.18 & 22 Sept. 2005 & 5.6 & 18.3 & 3.06 \\
28 Sept. 2004 & 4.7 & 19.2 & 2.52 & 7 Oct. 2005 & 4.4 & 17.6 & 1.89 \\
\hline
\end{tabular}

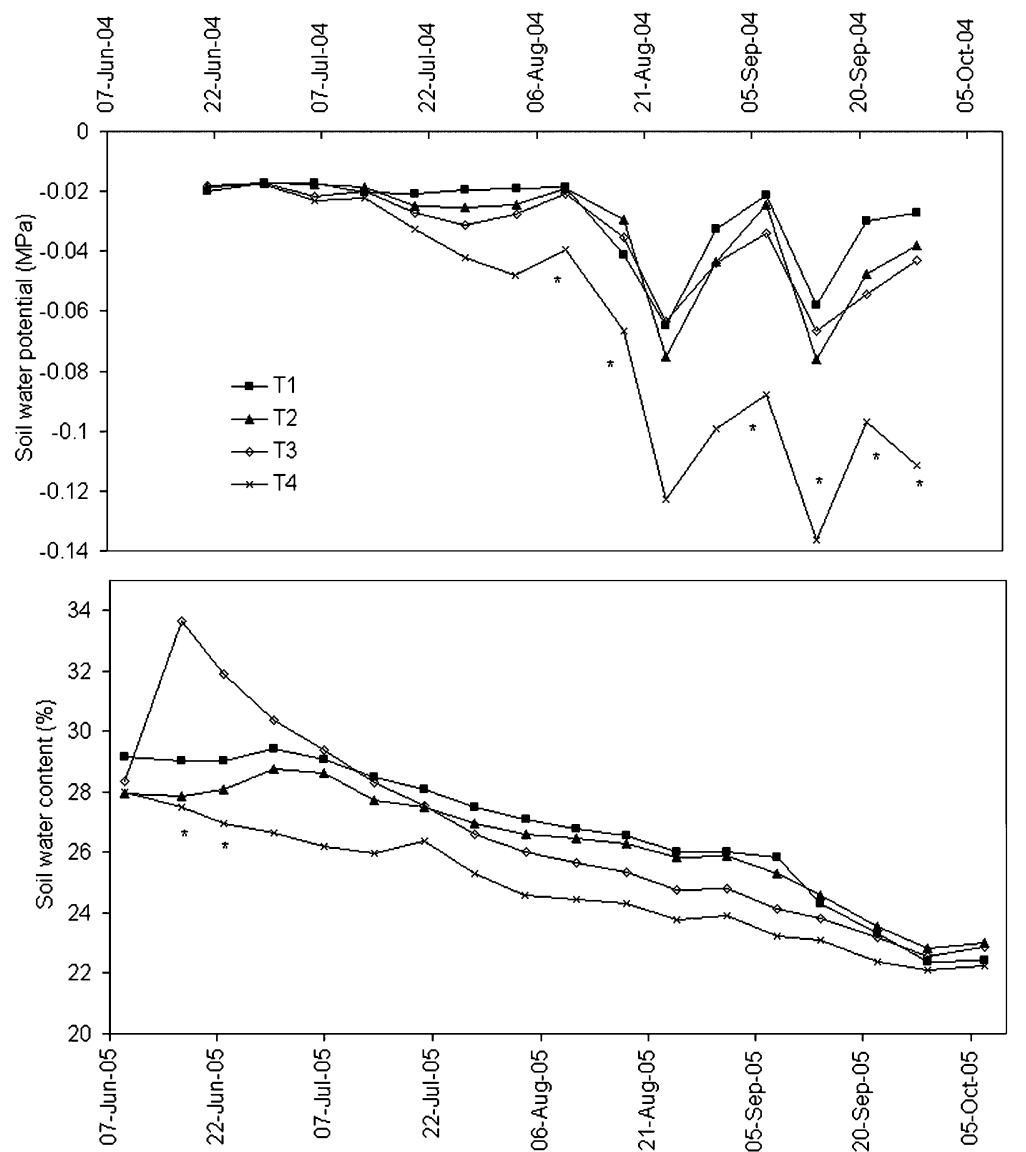

Fig. 2. Mean soil water potential at 0.70-m depth and $0.30 \mathrm{~m}$ from the drip emitter in 2004 and mean soil water content at $1-\mathrm{m}$ depth and $0.30 \mathrm{~m}$ from the drip emitter in 2005 under four irrigation treatments. T1 was irrigated to maintain soil close to water-holding capacity. T2, T3, and T4 received $82 \%, 64 \%$, and $46 \%$ of the water applied to T1 in 2004, respectively, and $76 \%, 72 \%$, and $29 \%$ of the water applied to T1 in 2005 , respectively. *Significant differences by Duncan's test at $P<0.05$. Average cv $=33 \%$. experimental period was reached on 30 June. In $\mathrm{T} 3$, a different pattern was obtained as a result of the valve failure. In that treatment, $\theta$ rose rapidly, reaching the highest $\theta$ value $4 \mathrm{~d}$ after the failure and then fell rapidly. The seasonal trend approached that of T4 in the second half of the season. Significant differences between treatments were only obtained on two occasions. $\theta$ in T3 was significantly higher than in T2 and T4 on 17 June and 23 June. No drainage was observed in any of the treatments, except in T3 after the valve failed and $\theta$ increased sharply.

Stem water potential and leaf conductance. Mean $\Psi_{\text {stem }}$ and $g_{1}$ data for 2004 and 2005 are presented in Table 2. Seasonal trends during 2004 and 2005 are shown in Figures 3 and 4. In 2005 , mean $\Psi_{\text {stem }}$ was over twice the value obtained in 2004 (Table 2). The highest value $(-0.35 \mathrm{MPa})$ was recorded on 12 July 2004 in T1 (Fig. 3), whereas the lowest value was recorded on 22 Sept. 2005 in T4 (-3.20 MPa). $\Psi_{\text {stem }}$ in T4 was $36 \%$ and $30 \%$ lower than that of T1 in 2004 and 2005, respectively. T3 and T4 values were significantly lower than those of T1 and T2 in both years. Leaf conductance differed throughout the season and between years (Table 2; Fig. 4). In 2005, gl was 31\% lower than in 2004. The highest $g_{1}$ value was reached on a humid day in August, and a second rise occurred on a mild day in September. In 2004, g $\mathrm{g}_{1}$ was not significantly different between treatments. However, in 2005, leaf conductance in T1 and T2 was not significantly different but was significantly higher than that in T4. Averaged over all data, leaf conductance in $\mathrm{T} 4$ was $12 \%$ lower than in $\mathrm{T} 1$.

Vegetative growth. The effect of irrigation on vegetative growth was quantified as olive height, leaf area development, shoot growth (Table 3), and trunk diameter (Fig. 5). At planting (9 June 2003), olive trees were $0.87 \pm$ $0.22 \mathrm{~m}$ high with a leaf area of $0.09 \pm 0.01 \mathrm{~m}^{2}$. In 2003 , trees increased $0.38 \pm 0.02 \mathrm{~m}$ in height and $0.14 \pm 0.01 \mathrm{~m}^{2}$ in leaf area. In 2004, irrigation treatment did not have a significant effect on any of the vegetative measurements and olives increased in height and leaf area by $0.59 \pm 0.05 \mathrm{~m}$ and $1.09 \pm 0.08 \mathrm{~m}^{2}$, respectively. In 2005, irrigation treatment did not have a significant effect on olive height (mean growth of $0.20 \pm 0.07 \mathrm{~m}$ ), but leaf area was significantly affected. At the end of 2005 , leaf area in T2, T3, and T4 were $2 \%$, $12 \%$, and $30 \%$ lower than in $\mathrm{T} 1$, respectively. Leaf area index evolution in T1 was 0.0133 , $0.0341,0.1925$, and 0.3925 at planting and the end of 2003, 2004, and 2005, respectively. In 2004, seasonal shoot growth (mean value $0.43 \mathrm{~m}$ ) was not significantly different between treatments. However, in 2005, shoot growth was significantly lower in T4 (52\%) than in the other treatments, which had a mean shoot growth of $0.19 \mathrm{~m}$. In 2004, the seasonal pattern of shoot growth increased linearly with time until the end of September (figure not shown). However, in 2005, it followed a hyperbolic pattern reaching a sequential plateau in July and August in T4 and T3, respectively, and in September in T1 and T2. Trunk diameter at planting was $4.20 \pm 1.22 \mathrm{~mm}$. Three 
years later, trunk diameter in $\mathrm{T} 1$ was 10 times greater $(40.96 \pm 3.78 \mathrm{~mm})$. The second and third growing seasons (from June until September) were the most important growth periods, because trunk diameter increased by 15 $\mathrm{mm}$ compared with $3 \mathrm{~mm}$ in the first growing season. Irrigation treatment did not have a significant effect on trunk diameter until 14 July 2005. At the end of the experiment, trunk diameter in T4 was $13 \%$ lower than in $\mathrm{T} 1$.

Canopy development. Irrigation treatment had a significant effect on some of the canopy characteristics described in 2005 (Table 4). Number of canopy leaf layers and leaf area density were $34 \%$ and $31 \%$ lower in T4 than in $\mathrm{T} 1$ in 2005 , whereas porosity increased by $51 \%$. No significant differences were observed between irrigation treatments in external surface area or canopy volume. At the end of the third growing season, experimental olive trees occupied only $23 \%$ and $43 \%$ of the potential volume and surface area considering that a hedgerow could be $2 \mathrm{~m}$ high and $1 \mathrm{~m}$ wide. The soil covered by the canopy was $6 \%, 10 \%$, and $22 \%$ in 2003,2004 , and 2005 , respectively.

Flowering. In 2005, trees developed few inflorescences per tree $(16 \pm 45)$, and there

Table 2. Mean stem water potential and leaf conductance at solar noon throughout the 2004 and 2005 seasons. $^{z}$

\begin{tabular}{lccccc}
\hline & \multicolumn{2}{c}{ Stem water potential $(\mathrm{MPa})$} & & \multicolumn{2}{c}{ Leaf conductance $\left(\mathrm{mmol} \mathrm{H}_{2} \mathrm{O} / \mathrm{m}^{2} / \mathrm{s}\right)$} \\
\cline { 2 - 3 } \cline { 5 - 6 } Treatment & $2004^{\mathrm{y}}$ & 2005 & & 2004 & 2005 \\
\hline T1 & $-0.74 \mathrm{a}$ & $-1.71 \mathrm{a}$ & & 404 & $\mathrm{a}$ \\
T2 & $-0.71 \mathrm{a}$ & $-1.83 \mathrm{~b}$ & & 394 & $280 \mathrm{a}$ \\
T3 & $-0.90 \mathrm{~b}$ & $-2.05 \mathrm{c}$ & & 381 & $249 \mathrm{~b}$ \\
T4 & $-1.01 \mathrm{c}$ & $-2.23 \mathrm{~d}$ & & 376 & $226 \mathrm{c}$ \\
\hline
\end{tabular}

${ }^{\mathrm{z}} \mathrm{T} 1$ was irrigated to maintain soil close to water-holding capacity. T2, T3, and T4 received $82 \%, 64 \%$, and $46 \%$ of the water applied to T1 in 2004, respectively, and $76 \%, 72 \%$, and $29 \%$ of the water applied to T1 in 2005 , respectively. Average $\mathrm{cv}=25 \%, 7 \%, 10 \%$, and $13 \%$ for each parameter, respectively.

'Treatments with the same letter are not significantly different by Duncan's test at $P<0.05$.

were no significant differences between irrigation treatments (Table 5). In 2006, inflorescence production increased by $123 \%$. No significant differences were observed in inflorescence number between irrigation treatments as a result of high variability $(\mathrm{CV}=188 \%)$.

\section{Discussion}

Compared with other fruit crops, olive is characterized by a long unproductive period. Thus, crop management during the years after planting is focused on reducing this period. Olive production during the first few years depends on how the canopy covers the hedgerow to intercept maximum radiation. Canopy development of the experimental trees was determined by climatic conditions, hedgerow density, olive training system, and irrigation. The experiment was carried out near the Tajo Valley in Madrid, which is a cold area for olive trees. Leaf area of the highly irrigated olive trees (T1) was 133, 341, 1925, and 3925 $\mathrm{m}^{2} /$ ha at planting and at the end of the first, second, and third years, respectively (Table 3 ), which is much lower than observed in the less vigorous cv. Arbequina in a warm area in Andalucía, Spain (Testi et al., 2004). As

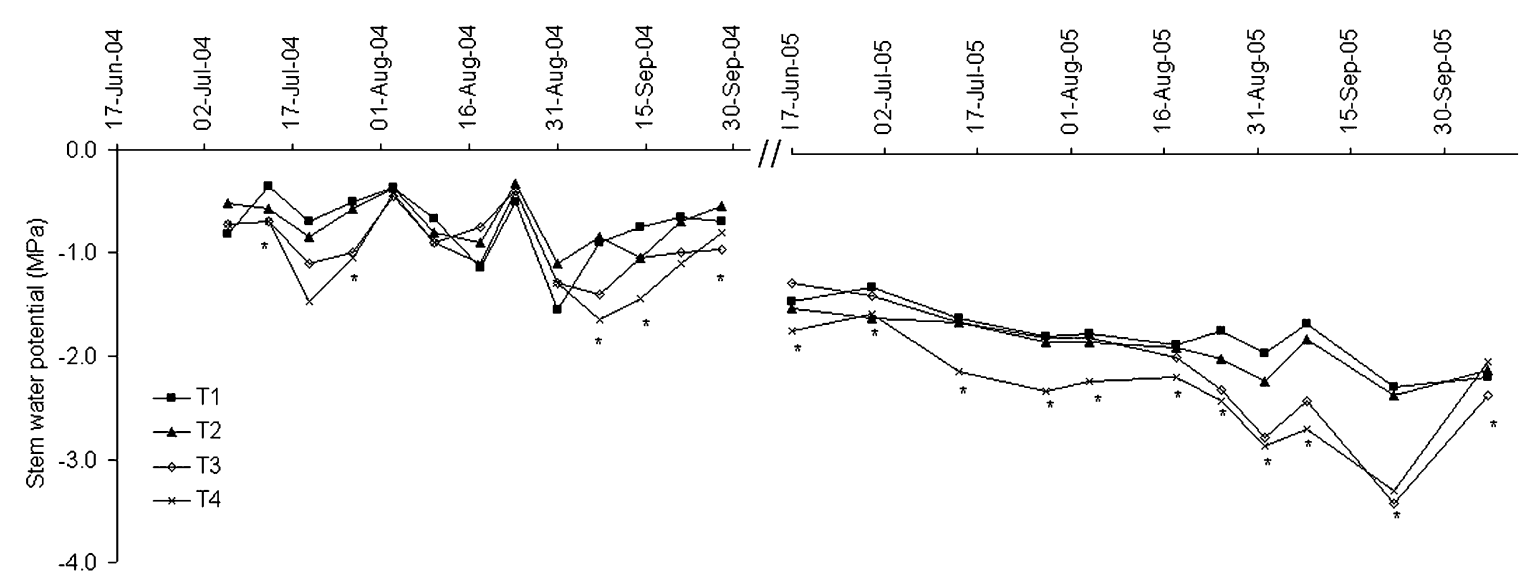

Fig. 3. Stem water potential at solar noon in the second and third growing seasons under various irrigation treatments. T1 was irrigated to maintain soil close to water-holding capacity. T2, T3, and T4 received $82 \%, 64 \%$, and $46 \%$ of the water applied to T1 in 2004 , respectively, and $76 \%, 72 \%$, and $29 \%$ of the water applied to T1 in 2005, respectively. *Significant differences by Duncan's test at $P<0.05$. Average cv $=30 \%$.

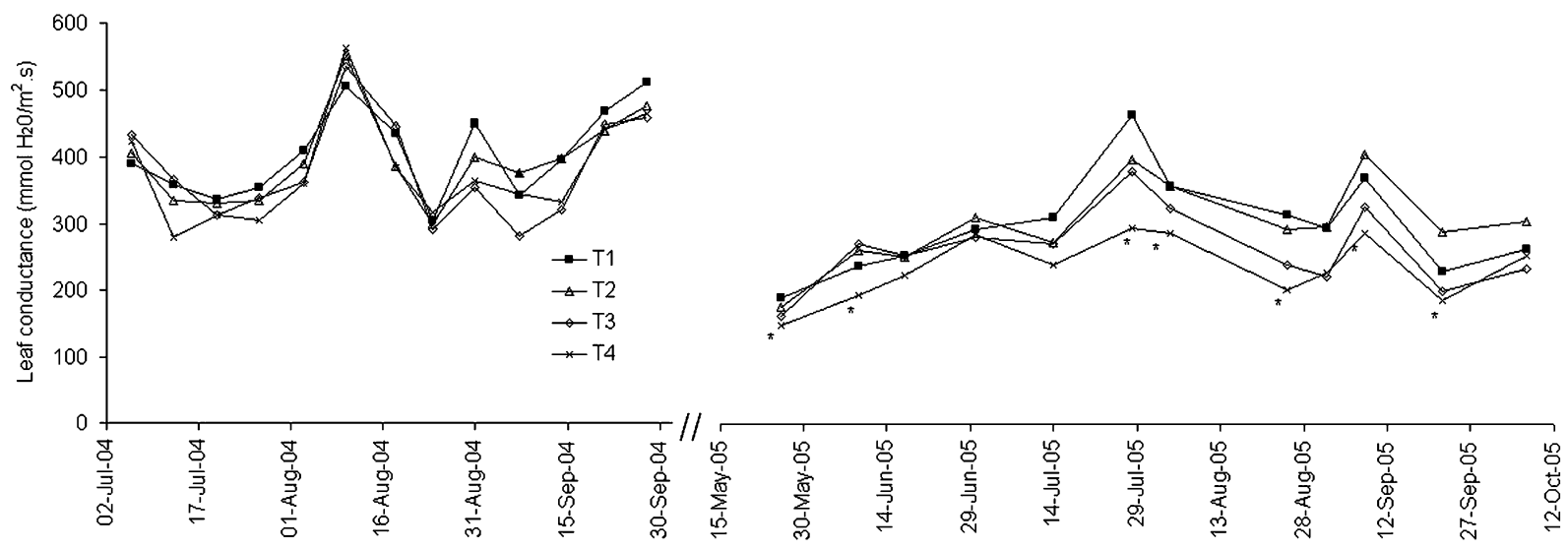

Fig. 4. Leaf conductance at solar noon in the second and third growing seasons under various irrigation treatments. T1 was irrigated to maintain soil close to waterholding capacity. T2, T3, and T4 received $82 \%, 64 \%$, and $46 \%$ of the water applied to T1 in 2004, respectively, and $76 \%, 72 \%$, and $29 \%$ of the water applied to $\mathrm{T} 1$ in 2005, respectively. *Significant differences by Duncan's test at $P<0.05$. Average cv $=12 \%$. 
Table 3. Olive tree height, tree leaf area, and mean shoot length at the end of the second and third growing seasons. ${ }^{\mathrm{z}}$

\begin{tabular}{|c|c|c|c|c|c|c|}
\hline \multirow[b]{2}{*}{ Treatment } & \multicolumn{3}{|c|}{ Sept. 2004} & \multicolumn{3}{|c|}{ Sept. 2005} \\
\hline & $\begin{array}{c}\text { Olive tree } \\
\text { ht }(\mathrm{m})\end{array}$ & $\begin{array}{l}\text { Tree leaf } \\
\text { area }\left(\mathrm{m}^{2}\right)\end{array}$ & $\begin{array}{c}\text { Shoot } \\
\text { length }(\mathrm{m})\end{array}$ & $\begin{array}{c}\text { Olive tree } \\
\text { ht (m) }\end{array}$ & $\begin{array}{c}\text { Tree leaf } \\
\text { area }\left(\mathrm{m}^{2}\right)^{\mathrm{y}}\end{array}$ & $\begin{array}{c}\text { Shoot } \\
\text { length (m }\end{array}$ \\
\hline T1 & 1.85 & 1.30 & 0.43 & 2.02 & $2.65 \mathrm{a}$ & $0.19 \mathrm{a}$ \\
\hline $\mathrm{T} 2$ & 1.83 & 1.36 & 0.44 & 2.11 & $2.60 \mathrm{a}$ & $0.19 \mathrm{a}$ \\
\hline $\mathrm{T} 3$ & 1.89 & 1.40 & 0.43 & 2.12 & $2.32 \mathrm{a}$ & $0.18 \mathrm{ab}$ \\
\hline $\mathrm{T} 4$ & 1.84 & 1.22 & 0.42 & 1.97 & $1.85 \mathrm{~b}$ & $0.09 \mathrm{~b}$ \\
\hline
\end{tabular}

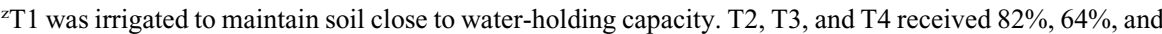
$46 \%$ of the water applied to T1 in 2004, respectively, and $76 \%, 72 \%$, and $29 \%$ of the water applied to T1 in 2005 , respectively. Average $\mathrm{CV}=10 \%, 32 \%, 9 \%, 8 \%, 33 \%$, and 38\% for each parameter, respectively.

'Treatments with the same letter are not significantly different by Duncan's test at $P<0.05$.

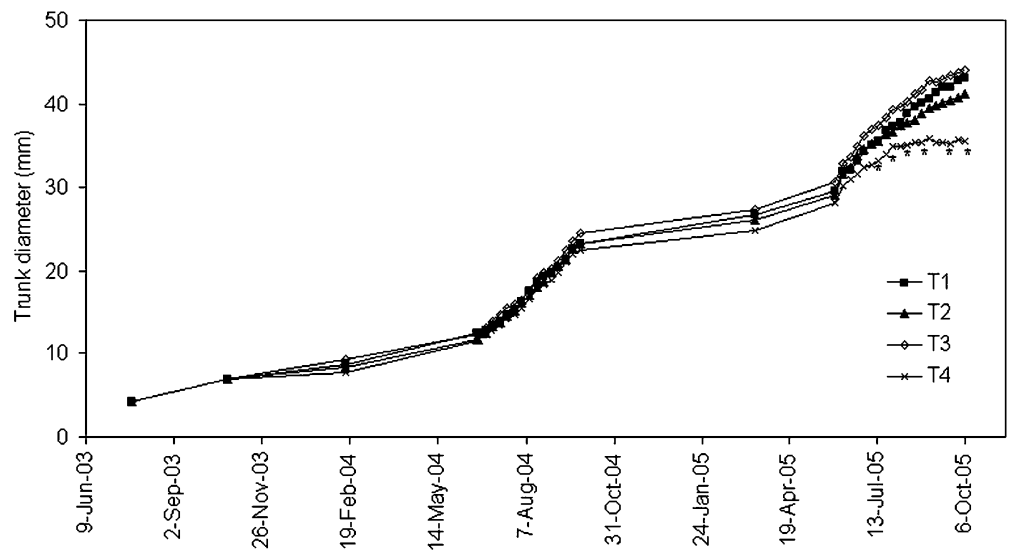

Fig. 5. Trunk diameter of young olive cv. Cornicabra from planting until the third growing season under various irrigation treatments. T1 was irrigated to maintain soil close to water-holding capacity. T2, T3, and T4 received $82 \%, 64 \%$, and $46 \%$ of the water applied to T1 in 2004, respectively, and $76 \%, 72 \%$, and $29 \%$ of the water applied to T1 in 2005, respectively. ${ }^{*}$ Significant differences by Duncan's test at $P<0.05$. Average cv $=9 \%$.

Table 4. Canopy characteristics: external surface area, volume, number of leaf layers, and porosity at the end of the third growing season $(2005)^{\mathrm{z}}$

\begin{tabular}{lccccc}
\hline Treatment & $\begin{array}{c}\text { External surface } \\
\text { area }\left(\mathrm{m}^{2} / \mathrm{ha}\right)\end{array}$ & $\begin{array}{c}\text { Volume } \\
\left(\mathrm{m}^{3} / \mathrm{ha}\right)\end{array}$ & $\begin{array}{c}\text { Leaf layers } \\
(\text { number })^{\mathrm{y}}\end{array}$ & $\begin{array}{c}\text { Leaf area } \\
\text { density }\left(\mathrm{m}^{2} / \mathrm{m}^{3}\right)\end{array}$ & $\begin{array}{c}\text { Porosity } \\
(\%)\end{array}$ \\
\hline T1 & 5524 & 1185 & $2.57 \mathrm{a}$ & $3.55 \mathrm{a}$ & $19.8 \mathrm{a}$ \\
T2 & 5598 & 1155 & $2.35 \mathrm{ab}$ & $3.41 \mathrm{ab}$ & $21.4 \mathrm{a}$ \\
T3 & 6117 & 1348 & $1.95 \mathrm{bc}$ & $2.58 \mathrm{ab}$ & $20.5 \mathrm{a}$ \\
T4 & 5776 & 1214 & $1.70 \mathrm{c}$ & $2.44 \mathrm{~b}$ & $29.8 \mathrm{~b}$ \\
\hline
\end{tabular}

${ }^{\mathrm{z}} \mathrm{T} 1 \mathrm{w}$ wa irrigated to maintain soil close to water-holding capacity. T2, T3, and T4 received $82 \%, 64 \%$, and $46 \%$ of the water applied to T1 in 2004, respectively, and $76 \%, 72 \%$, and $29 \%$ of the water applied to T1 in 2005 , respectively. Average $\mathrm{CV}=18 \%, 23 \%, 17 \%, 21 \%$, and $21 \%$ for each parameter, respectively.

'Treatments with the same letter are not significantly different by Duncan's test at $P<0.05$.

a result of the high density of the hedgerow orchard (1481 olive/ha), the canopy volume obtained in the third year was similar to that obtained by Pérez-López et al. (2008) in the fifth year in 300 trees/ha of the same cultivar under similar climatic conditions. Nevertheless, training trees to a central leader resulted in a soil cover of $22 \%$ in the third year, which was similar to that obtained by Testi et al. (2004). Canopy development occurred differently each year. During the first 2 years, trees increased in height up to $1.8 \mathrm{~m}$. However, leaf area development mainly occurred during the third year (Table 3). In both years, shoot growth increased almost linearly with time until September, and no summer delay was observed under nonwater stress conditions. Total shoot growth in the third year was less than half of that obtained in the second year. This may be the result of the lower number of growth points in that year.
Olive behavior also differed between years in hydration and stomatal activity in highly irrigated olives (Table 2; Figs. 3 and 4). In the third year, mean $\Psi_{\text {stem }}$ and $g_{1}$ in $\mathrm{T} 1$ decreased $131 \%$ and $31 \%$, respectively, compared with the second year. Although a valve failed in T3 on 13 June 2005 and high soil water content was measured, $\mathrm{g}_{1}$ did not reach the high values recorded in 2004 on days with a similar VPD. These lower $g_{1}$ values observed with the increase in olive age under similar atmospheric and soil water conditions could be the result of a greater distance between roots and leaves, because olive has been reported to have high hydraulic resistance (Fernández and Moreno, 1999). The higher tree leaf area in the third year also modified tree physiology by increasing transpiration and reducing $\Psi_{\text {stem }}$ and $g_{1}$. In both years, similar $g_{1}$ trends were observed (Fig. 4). The highest $g_{1}$ value was reached on a
Table 5. Olive inflorescence number per tree in 2005 and $2006 .^{\mathrm{z}}$

\begin{tabular}{lcc}
\hline Treatment & $\begin{array}{c}\text { Inflorescences } \\
\text { (number/tree) }\end{array}$ & $\begin{array}{c}\text { Inflorescences } \\
\text { (number/tree) }\end{array}$ \\
\hline T1 & 2005 & 2006 \\
T2 & 21 & 2993 \\
T3 & 5 & 1941 \\
T4 & 30 & 2128 \\
\hline
\end{tabular}

zT1 was irrigated to maintain soil close to waterholding capacity. T2, T3, and T4 received $82 \%$, $64 \%$, and $46 \%$ of the water applied to T1 in 2004, respectively, and $76 \%, 72 \%$, and $29 \%$ of the water applied to T1 in 2005, respectively. No significant differences by Duncan's test at $P<0.05$. Average $\mathrm{CV}=188 \%$.

humid day in August and a second rise was observed in September.

Water shortage is an important limitation in many olive orchard areas and irrigation water should be optimized. As a result of irregular root distribution, water management is difficult in young trees. When emitters are not placed beside the tree, long irrigations are applied to ensure that the root volume is wetted, which may cause sanitary problems such as verticillium wilt and a lack of oxygen for optimum root growth. Optimum water management should involve applying a minimum amount of water for maximum growth with no reduction in bud initiation. In this experiment, T1 was irrigated to maintain soil close to water-holding capacity, receiving 56 and $106 \mathrm{~mm}$ in the second and third years, respectively. T2, T3, and $\mathrm{T} 4$ received $82 \%$, $64 \%$, and $46 \%$ of the water applied to $\mathrm{T} 1$ during the second year and $76 \%, 72 \%$, and $29 \%$ during the third years, respectively. The irrigation treatments produced different levels of water stress each year, evaluated as soil water status, $\Psi_{\text {stem }}$, and $g_{1}$. In the second year, high spring and summer rainfall (Fig. 1) and low leaf area development did not produce significant differences in $\Psi_{\text {soil }}$ between irrigation treatments until August (Fig. 2), and significant differences were not observed in $\Psi_{\text {stem }}$ between treatments until 1 month later (Fig. 3). The third year was very dry and significant differences in $\Psi_{\text {stem }}$ and $g_{1}$ values were found between irrigation treatments in early June. $\Psi_{\text {stem }}$ was more sensitive to irrigation treatment than $\mathrm{g}_{1}$, as observed by Moriana and Fereres (2002). The water stress provoked by the experimental treatments was lower than in other hedgerow experiments. The lowest $\Psi_{\text {stem }}$ value obtained $(-3.2 \mathrm{MPa})$ was not as low as $-4.1 \mathrm{MPa}$ reported by Grattan et al. (2006).

Although the different water irrigations applied in T1 and T3 produced different water stress conditions, the higher water irrigation applied in $\mathrm{T} 1$ did not result in higher vegetative growth or inflorescence per tree than in T3. Although T3 was irrigated with $64 \%$ and $72 \%$ of the water applied to T1 in the second and third years, respectively, and $\Psi_{\text {stem }}$ and $g_{1}$ were significantly lower in T3, no significant differences were observed between $\mathrm{T} 1$ and $\mathrm{T} 3$ in any of the vegetative 
measurements (Table 3; Fig. 5), canopy development (Table 4), or inflorescence number (Table 5).

When irrigation was greatly reduced (T4), leaf area, shoot growth, and trunk diameter in the third year were significantly lower than in T1 (Table 3; Fig. 5). Shoot growth was found to be the most sensitive vegetative parameter. Canopy characteristics were also modified. A lower number of leaf layers, lower leaf area density, and higher porosity were observed in T4 compared with T1 (Table 4).

In this experiment, water stress did not enhance flowering as observed in other fruit crops (Meilan, 1997) and adult olive (Gucci et al., 2007). Inflorescence number was highly variable but was not significantly determined by tree vigor (diameter or leaf area) or inflorescence number the year before. Flowering variability is characteristic of cv. Cornicabra during the first years.

Considering that during the second and third years neither the vegetative nor the reproductive behavior of $\mathrm{T} 3$ olives was significantly different from $\mathrm{T} 1$, irrigation treatment T3 could be considered the most efficient irrigation strategy.

\section{Literature Cited}

Allen, R.G., L.S. Pereira, D. Raes, and M. Smith. 1998. Crop evapotranspiration. Guidelines for computing crop water requirements. Irrigation and drainage paper 56. FAO, Rome, Italy.

Baktir, I., S. Ulger, L. Kaynak, and D.G. Himelrick. 2004. Relationship of seasonal changes in endogenous plant hormones and alternate bearing of olive trees. HortScience 39:987-990.

Barranco, D. 2008. Variedades y patrones, p. 6592. In: Barranco, D., R. Fernández-Escobar, and L. Rallo (eds.). El cultivo del olivo. MundiPrensa, Madrid, Spain.

Begg, J.E. and N.C. Turner. 1970. Water potential gradients in field tobacco. Plant Physiol. 46:343-346.

Davies, W.J., J. Metcalfe, T.A. Lodge, and A.R. da Costa. 1986. Plant growth substances and the regulation of growth under drought. Aust. J. Plant Physiol. 13:105-125.

Fernández, J.E. and F. Moreno. 1999. Water use by the olive tree. J. Crop Prod. 2:101-162.

Gomez-del-Campo, M., A. Leal, and C. Pezuela. 2008. Relationship of stem water potential and leaf conductance to vegetative growth of young olive trees in a hedgerow orchard. Aust. J. Agr. Res. 59:270-279.

Grattan, S.R., M.J. Berenguer, J.H. Connell, V.S. Polito, and P.M. Vossen. 2006. Olive oil pro- duction as influenced by different quantities of applied water. Agr. Water Mgt. 85:133-140.

Gucci, R., E. Lodolini, and H.F. Rapoport. 2007. Productivity of olive trees with different water status and crop load. J. Hort. Sci. Biotechnol. 82:648-656.

Kitsaki, C.K. and J.B. Drossopoulos. 2005. Environmental effect on ABA concentration and water potential in olive leaves (Olea europaea L. cv 'Koroneiki') under non-irrigated field conditions. Environ. Exp. Bot. 54:77-89.

McCutchan, H. and K.A. Shackel. 1992. Stem-water potential as a sensitive indicator of water stress in Prune trees (Prunus domestica L. cv. 'French'). J. Amer. Soc. Hort. Sci. 117:607-611.

Meilan, R. 1997. Floral induction in woody angiosperms. New For. 14:179-202.

Morettini, A. 1972. Olivicoltura. Ramo Editoriale Degli Agricoltori, Rome, Italy.

Moriana, A. and E. Fereres. 2002. Plant indicators for scheduling irrigation of young olive trees. Irrig. Sci. 21:83-90.

Pérez-López, D., A. Moriana, H. Rapoport, N. Olmedilla, and F. Ribas. 2008. New approach for using trunk growth rate and endocarp development in the irrigation scheduling of young olive orchards. Scientia Hort. 115:244-251.

Testi, L., F.J. Villalobos, and F. Orgaz. 2004. Evapotranspiration of a young irrigated olive orchard in southern Spain. Agr. For. Meteorol. 121:1-18. 